\title{
Sosialisasi Kesantunan Berbahasa di Media Sosial Pada Pelajar SMA Islam Al Azhar 5 Cirebon
}

\author{
Maya Dewi Kurnia*, Elin Rosmaya, Sobihah Rasyad \\ Universitas Swadaya Gunung Jati, Cirebon, Indonesia \\ *Coresponding Author: mayadewi4142@gmail.com \\ Dikirim: 10-06-2021 ; Direvisi: 11-06-2021 ; Diterima: 12-06-2021
}

\begin{abstract}
Abstrak: Bahasa menunjukan cerminan diri. Orang yang berbahasa dengan santun maka menunjukan karakter dirinya. Dalam komunikasi lisan maupun tulisan bahasa yang digunakan tentu harus memperhatikan sikap santun. Namun kenyataannya pengguna bahasa tidak acuh dengan kesantunan berbahasa terutama di media sosial. Di era digital ini pengguna media social didominasi kalangan muda yang berada pada rentang usia 18-24 tahun dengan jumlah pria lebih banyak 18 persen dibandingkan wanita. Melalui angket yang sudah disebarkan kepada pelajar di SMA Al Azhar 5 Cirebon sebagian siswa tidak mengetahui tentang kesantunan berbahasa. Ketidaktahuan etika komunikasi di media tersebut yang membuat pengguna bahasa khususnya pelajar dengan mudah memberikan komentar kasar atau penghinaan. Berdasarkan kondisi tersebut kegiatan pengabdian masyarakat bertajuk Sosialisasi Kesantunan Berbahasa Di Media Sosial Pada Pelajar SMA Al Azhar 5 Cirebon dilaksanakan. Solusi yang ditawarkan dari pengabdian ini memberikan sosialisasi kepada pelajar SMA Al Azhar 5 Cirebon tentang kesantunan berbahasa melalui media daring zoom meeting. Tujuan pengabdian ini yakni memberikan pengetahuan tentang kesantunan berbahasa di media social kepada pelajar SMA Al Azhar 5 Cirebon; memberikan pengetahuan etika komunikasi; menyosialisasikan tentang UU ITE Cirebon. Metode pengabdian yang digunakan dalam kegiatan PKM ini adalah ceramah, tanya jawab. Hasil yang diperoleh mahasiswa antusias dan memiliki keinginan untuk bisa menerapkan pengetahuan yang diperoleh dalam keseharian.
\end{abstract}

Kata Kunci: kesantunan berbahasa; media sosial; sosialisasi

Abstract: Language shows a reflection of oneself. People who speak politely show their character. In oral and written communication, the language used must pay attention to politeness. However, in reality, language users are not indifferent to language politeness, especially on social media. In this digital era, social media users are dominated by young people who are in the age range of 18-24 years with 18 percent more men than women. Through a questionnaire that has been distributed to students at SMA Al Azhar 5 Cirebon, some students do not know about language politeness. Ignorance of communication ethics in the media makes it easy for language users, especially students, to give rude comments or insults. Based on these conditions, a community service activity entitled Socialization of Language Politeness in Social Media for Al Azhar 5 Cirebon High School Students was carried out. The solution offered from this service provides socialization to students of SMA Al Azhar 5 Cirebon about language politeness through online media zoom meetings. The purpose of this service is to provide knowledge about language politeness on social media to students of SMA Al Azhar 5 Cirebon; provide knowledge of communication ethics; socialize the Cirebon ITE Law. The service method used in this PKM activity is lecture, question and answer. The results obtained by students are enthusiastic and have the desire to be able to apply the knowledge gained in everyday life.

Keywords: language politeness1; social media; socialization

@ 2021 JagoMipa (https://bimaberilmu.com/jurnal/index.php/jagomipa) 


\section{PENDAHULUAN}

Sejak beberapa tahun belakangan media sosial berkembang pesat di Indonesia. Diantara negara Asia lainnya, Indonesia urutan keempat pengguna media sosial paling banyak setelah Jepang. Bahkan Januari 2019 hasil riset Wearesosial Hootsuite yang dikutip dari sebuah situs berita Kompas Online menyebutkan pengguna media sosial di Indonesia mencapai 150 juta atau sebesar 56\% dari total populasi. Jumlah tersebut meningkat $20 \%$ dari survey sebelumnya. Penggunanya didominasi oleh kalangan muda yang berada pada rentang usia 18-24 tahun dengan jumlah pria lebih banyak 18 persen dibandingkan wanita dengan persentasi 15 persen. Namun kebanyakan dari mereka menggunakan media sosial seperti facebook, istagram, dan youtube untuk mendapatkan hiburan dan menyebarkan informasi. Sekait hal itu bahasa menjadi penting karena alat penyampai informasi.

Bahasa merupakan cerminan karakter dan watak seseorang. Orang yang berbahasa santun akan menunjukan pribadi yang baik. Sebaliknya orang yang berbahasa dengan cara menghujat, kasar, mencela maka maka menunjukan pribadi yang tidak berbudi.

Hal ini yang sering dilupakan pengguna media sosial. Kebebasan berpendapat membuat masyarakat terlena sehingga tidak acuh pada etika berkomunikasi dan melanggar kesantunan berbahasa. Akibatnya terjadi konflik atau kesalahpahaman karena komentar, kritik, saran, serta gurauan yang disampaikan pengguna media sosial yang tidak memperhatikan kesantunan berbahasa tersebut. Merujuk hal tersebut Leech menjelaskan pinsip kesantunan berbahasa itu perlu diketahui penutur dan mitra tutur agar tuturan yang bersifat emosi dapat dihindarkan. Dikemukakan Leech (2011:206) memberi paparan teori tentang kesantunan berbahasa. Secara umum,prinsipkesantunan menurut pendapat beliau terdiri dari 6 maksim (ketentuan, ajaran). Keenam maksim tersebut adalah 1) kebijaksanaan, 2) penerimaan, 3) kemurahan, 4) kerendahan hati, 5) kecocokan, dan 6) kesimpatian.

Penggunaan bahasa yang tidak santun tentu tidak dapat dibiarkan karena dapat memberikan contoh buruk pada masyarakat dalam berbahasa. Belum lagi apabila pengguna media sosial tidak berhati-hati dalam menyampaikan informasi atau berkomentar di media sosial bisa terkena sanksi pidana sebab melanggar UU No 19 tahun 2016 tentang Informasi dan Transaksi Elektronik ( ITE). Salah satu pasal dari UU tersebut menyebutkan setiap orang yang dengan sengaja dan tanpa hak mendistribusikan dan/ atau mentranmisikan dan/atau membuat dapat diaksesnya informasi elektronik dan/atau dokumen elektronik yang memiliki muatan penghinaan dan/ atau pencemaran nama baik sebagaimana dimaksud dalam pasal 27 ayat (3) dipidana dengan pidana penjara paling lama 4 (empat) tahun dan/ atau denda paling banyak Rp 750.000.000,00(tujuh ratus lima puluh juta rupiah).

Kenyataannya tidak sedikit pengguna media sosial seperti facebook yang melakukan ujaran penghinaan di media lalu berakhir di penjara. Seperti halnya dengan salah seorang pelajar di Sukabumi tahun 2018 lalu yang dilansir dari situs berita Kompas (3/3/2018) melakukan penyebaran informasi elektronik bermuatan ujaran kebencian. Akibatnya pelajar tersebut terancam 6 tahun penjara dan denda maksimal 1 milyar. Maka dari itu penting bagi pengguna media sosial khususnya kalangan pelajar untuk dapat menyampaikan informasi atau memberikan saran dan 
berkomentar dengan bahasa yang santun. Ketidaktahuan pelajar dalam etika berkomunikasi di media sosial menjadi faktor munculnya kasus pelajar sebagai pelaku pencemaran nama baik di media sosial. Berdasarkan angket yang sudah disebarkan kepada pelajar di SMA Al Azhar 5 Cirebon sebagian besar mereka mengatakan tidak tahu tentang kesantunan berbahasa di media sosial.

Dalam sebuah penelitian di Jurnal Stitilistika Vol 4. No 1 tahun 2007 yang ditulis Dr. Farida Nugrahani yang berjudul Penggunaan Bahasa dalam Media Sosial dan Implikasinya terhadap Karakter Bangsa diketahui bahwa terdapat penyimpangan penggunaan bahasa secara pragmatis dalam propaganda politik yang diunggah melalui media sosial. Penyimpangan tersebut berupa bentuk sarkasme yang sengaja dibuat untuk tujuan menyerang lawannya baik secara eksplisit maupun implisit. Bentuk sarkasme yang muncul membuktikan telah terjadi pelanggaran etika komunikasi sebagai wujud ketidaksantunan masyarakat Indonesia dalam berbahasa di media sosial.

Berdasarkan hal tersebut penulis tertarik untuk melakukan pengabdian masyarakat yang berjudul Sosialisasi Kesantunan Berbahasa di Media Sosial Pada Pelajar SMA Al Azhar 5, Cirebon. Dengan sosialiasi tersebut diharapkan pelajar sebagai pengguna aktif media sosial dapat lebih santun dalam berkomunikasi serta membangun kesadaran bijak dalam menggunakan media sosial. Selain itu melalui kegiatan diharapkan juga pelajar SMA khususnya memiliki pengetahuan sekait undang-undang Informasi dan Transaksi Elektronik (ITE).

\section{METODE PELAKSANAAN KEGIATAN}

Metode pendekatan yang digunakan untuk mengatasi permasalahan yang dihadapi mitra adalah dengan metode penyuluhan mengenai kesantunan berbahasa. Secara rinci kegiatan PKM dijelaskan sebagai berikut.Diskusi antara tim PKM dengan mitra untuk mengetahuai gambaran permasalahan yang dihadapi mitra, serta penentuan masalah utama yang akan dipecahkan dalam kegiatan PKM.

1. Koordinasi antara tim PKM, mitra dan narasumber untuk menentukan waktu pelaksanaan kegiatan, materi pelatihan dan jadwal kegiatan serta melakukan persiapan pelaksanaan kegiatan.

2. Pelaksanaan kegiatan pada tahap ini dilakukan yakni penyuluhan tentang kesantunan berbahasa melalui zoom meeting

3. Partisipasi mitra dalam pelaksanaan kegiatan meliputi :

a. Peserta didik mengikuti jadwal kegiatan yang telah disusun

b. Peserta didik mengamati materi yang disampaikan pemateri

4. Evaluasi.

Evaluasi dilakukan setelah PKM selesai dilaksanakan. Tujuan dari evalusi ini untuk mengetahui respons siswa terhadap kegiatan yang dilaksanakan. Evaluasi dilakukan dengan menyebarkan angket melalui google form.

\section{HASIL DAN PEMBAHASAN}

Kegiatan pengabdian kepada masyarakat ini dimulai pada awal Februari 2020 dengan kegiatan survey lokasi kegiatan. Pada kegiatan ini dilakukan wawancara dengan kepala sekolah dan guru bidang studi bahasa Indonesia di SMA Al Azhar 5 Cirebon untuk menentukan priorits masalah yang ingin 
diselesaikan bersama dengan tim PKM UGJ. Pada pertemuan ini ditemukan beberapa masalah antara lain sekait kesantunan berbahasa. Berdasarkan wawancara kepada guru ditemukan persoalan ketika siswa berkomunikasi melalui media sosial kepada guru misalnya yang cenderung kurang santun. Lalu guru memperlihatkan postingan atau komentar siswa di media sosial seorang tokoh. Komentar tersebut tidak dahulu dengan sapaan Bapak, ibu, mbak, dan kakak. Dari hal itu diketahui pengetahuan tentang etika komunikasi baik lisan dan tulisan di media sosial siswa juga minim.

Awalnya kegiatan ini ingin dilaksanakan secara langsung dengan tatap muka. Tetapi karena situasi pandemi kegiatan pelaksanaan kepada masyarakat baru bisa dilaksanakan pada Kamis, 1 Oktober 2020, pukul 10.00 WIB secara online melalui zoom meeting.

Adapun tahapan kegiatan dimulai dengan tahap pembukaan yang disampaikan oleh guru sebagai pembawa acara. Lalu dilanjutkan tim PKM UGJ oleh Elin Rosmaya, M.Pd selaku moderator acara. Pada bagian ini Elin Rosmaya, M.Pd mengenalkan nama tim serta tujuan dari kegiatan ini.

Berikutnya masuk pada sesi memaparkan materi tentang kesantunan berbahasa. Bagian ini dibawakan oleh TIM PKM UGJ, Maya Dewi Kurnia, S.S.,M.Pd. Materi dikemas dalam bentuk powerpoint. Siswa diingatkan untuk memperhatikan hal penting ketika berkomunikasi melalui media sosial diantaranya menggunakan sapaan dalam menyampaikan pendapat atau komentar di media sosial. Hal ini sebagai perwujudan penghargaan terhadap orang lain. Siswa diajak untuk menggunakan kata tolong, terima kasih, dan maaf. Selain itu menekankan pada siswa untuk menggunggah hal penting pada media sosial dibandingkan hal pribad dan menghindari ujaran kebencian. Sesi ini diikuti oleh 22 siswa kelas $\mathrm{X}$ dan 2 guru. Setelah sesi ini berakhir dilanjutkan dengan sesi tanya jawab. Beberapa siswa terlibat aktif mengajukan pertanyaan seputar kesantuan berbahasa di media sosial.

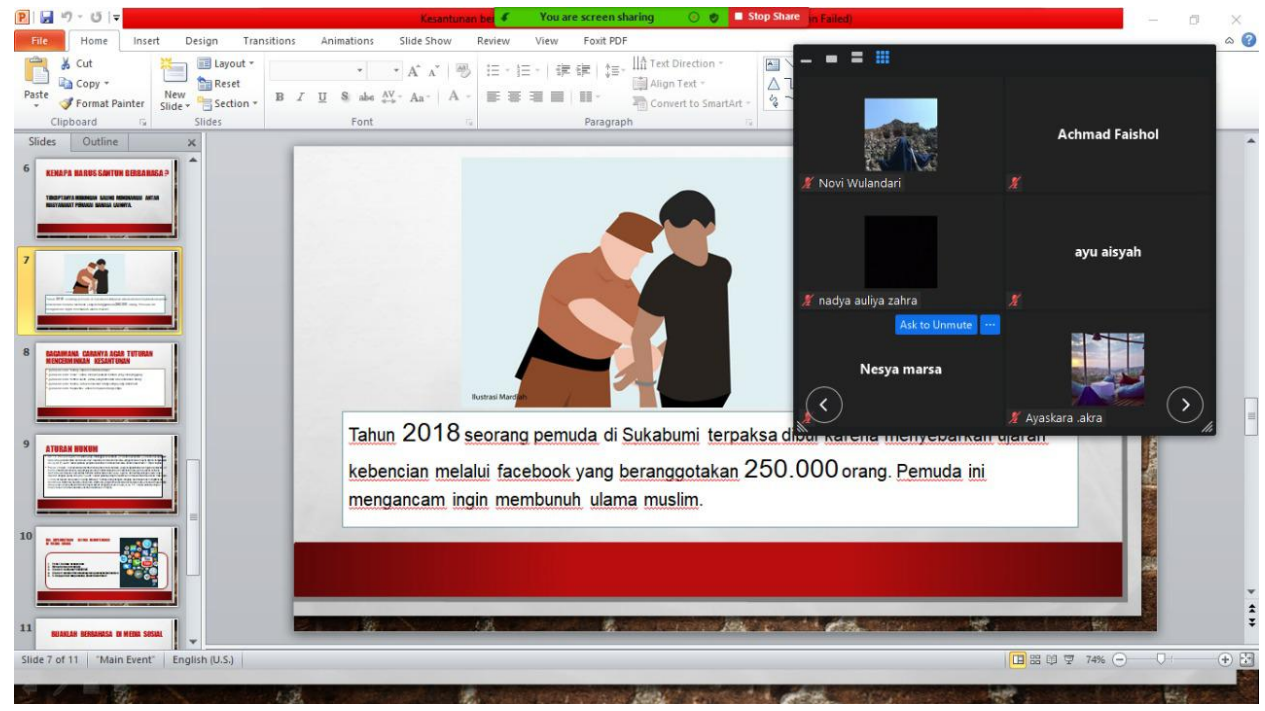

Gambar 1. Pemateri Menjelaskan Tentang Kesantunan Berbahasa

Selanjutnya siswa menyimak materi yang disampaikan pemateri seperti tampak pada gambar berikut. 


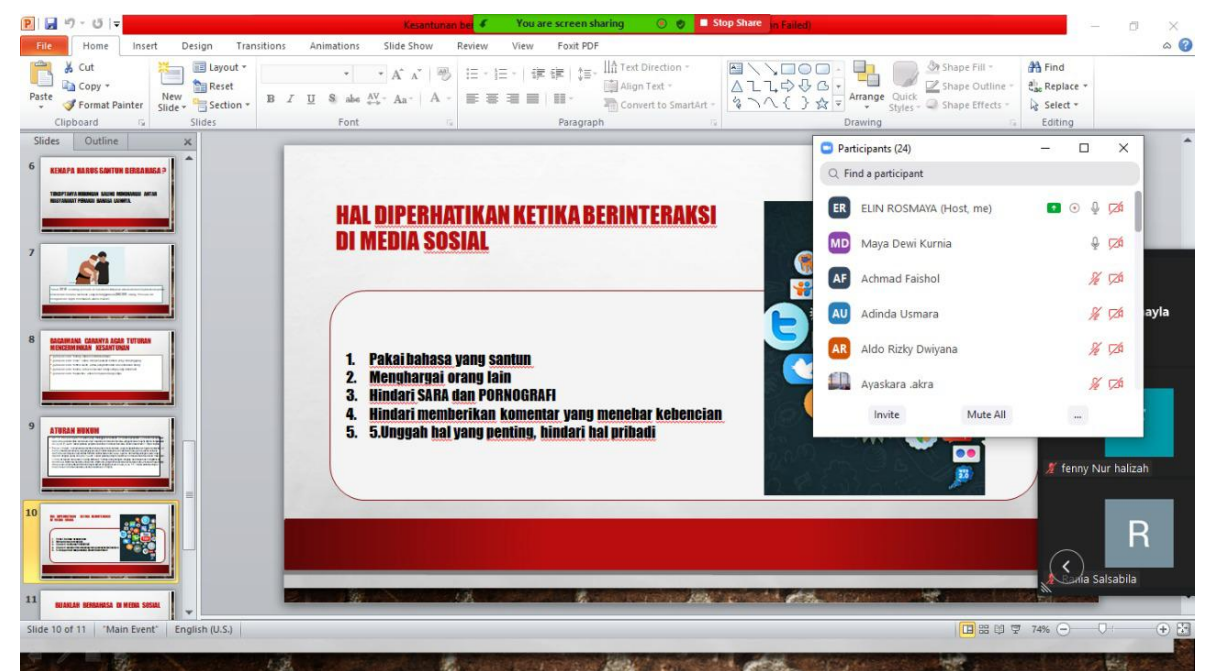

Gambar 2. Siswa Menyimak Materi Melalui Zoom Meeting

Setelah itu siswa mengisi angket respons tentang kegiatan yang diselenggarakan. Dari angket tesebut 95 persen diketahui mereka senang mengikutinya. Sebagian besar siswa mengatakan pengetahuan tentang kesantunan berbahasa dan etika berkomunikasi di media sosial bertambah. Dari angket tersebut juga diketahui ada siswa yang sudah mengetahuai kesantunan berbahasa ada juga yang belum. Dari 23 orang yang mengisi angket 11 orang menyebutkan belum pernah mendengar istilah kesantunan berbahasa. Dari sesi tanya jawab juga diketahui siswa tidak tahu sapaan seperti Bapak, Ibu, Kakak, dan Mas harus digunakan dalam membangun komunikasi di media sosial. Hal ini yang sering diabaikan oleh siswa, pengguna media sosial menganggap semua orang di media sosial sama sehingga menjadi leluasa berkomentar dan cenderung kasar. Sebelum menutup kegiatan tim PKM UGJ memberikan apresiasi kepada siswa yang berpartisipasi aktif dalam kegiatan berupa kuota.

Hasil kegiatan sosialisasi kesantunan berbahasa di media sosial kemudian diukur melalui respon siswa tentang materi. Reaksi mereka positif dan tergambar pada gambar berikut. Dari gambar di bawah diketahui sebagian besar siswa berharap pengetahuan akan kesantunan berbahasa di media sosial bertambah. Selain itu juga harapan mereka bisa menggunakan media sosial dengan bijak. Hal ini tergambar pada gambar berikut.

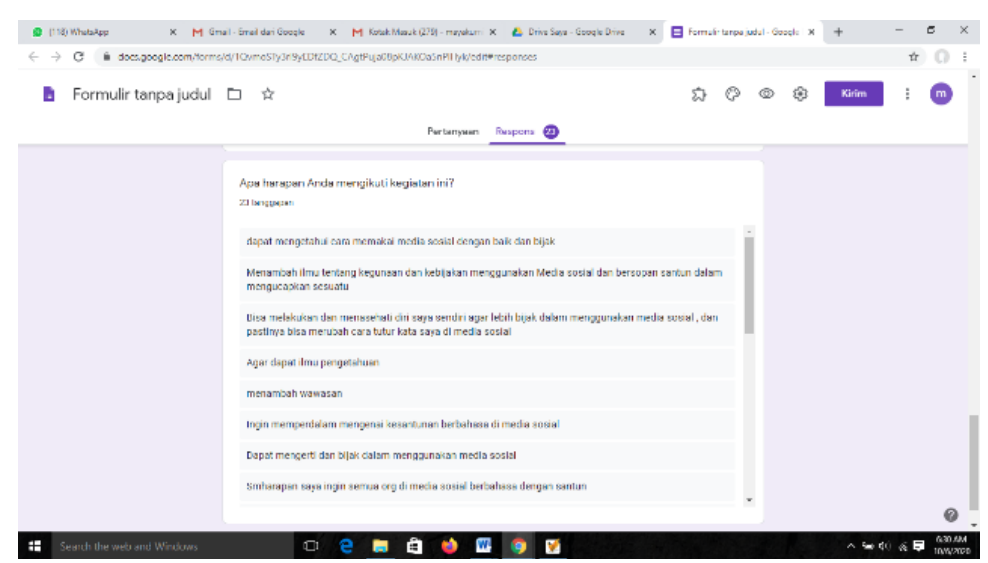

Gambar 3. Angket respons siswa tentang harapan mereka mengikuti kegiatan PKM 
Kegiatan pengabdian masyarakat yang telah dilaksanakan tanggal 1 Oktober 2020 ini juga telah dipublikasikan pada harian Kabar Cirebon, Sabtu, 3 Oktober 2020 .

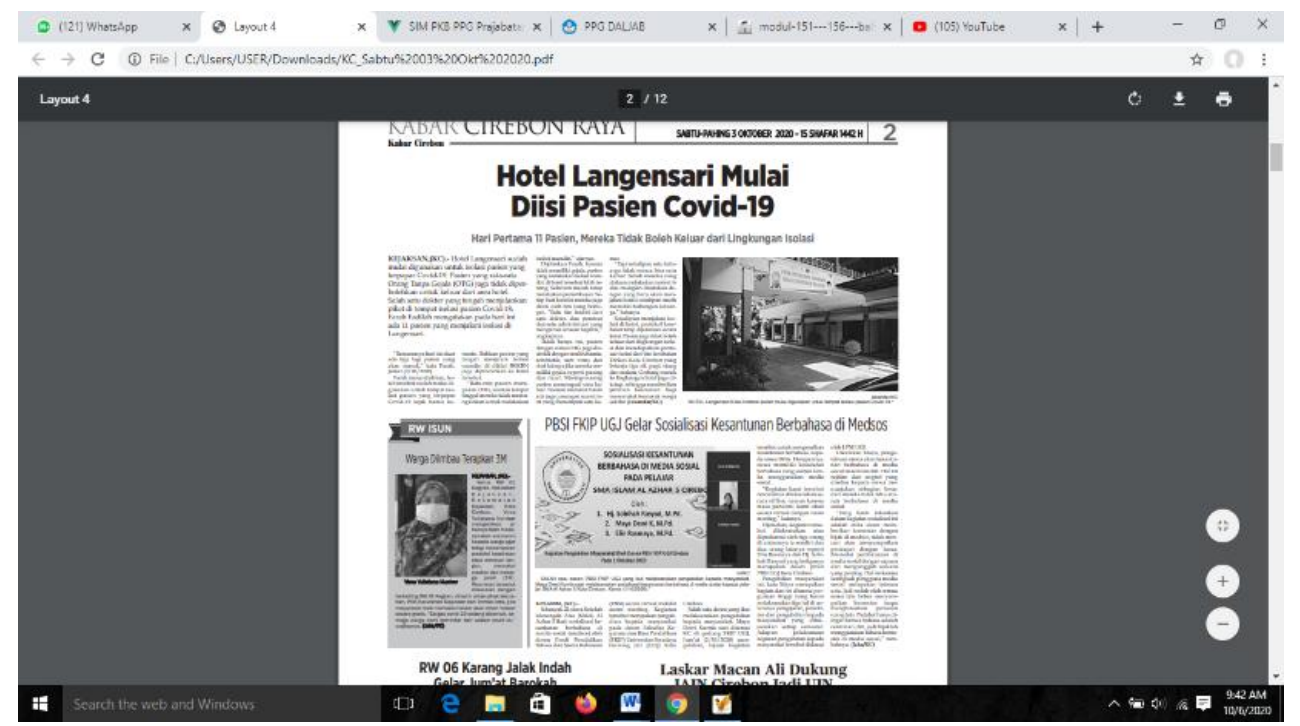

Gambar 4. Publikasi PKM pada Harian Kabar Cirebon

\section{KESIMPULAN}

Berdasarkan kegiatan pelaksanaan dan monitoring penyuluhan sosialisasi kesantunan berbahasa di media sosial pada pelajar SMA Al Azhar 5 Cirebon yang dilaksanakan pada Kamis, 1 Oktober yang dihadiri 22 orang siswa dan 2 orang guru telah berjalan lancar. Diharapkan kegiatan ini mampu meningkatkan pengetahuan, pemahaman siswa tentang kesantunan berbahasa. Dengan demikian akan terbangun kesadaran berbahasa yang santun dalam berkomunikasi lisan dan tulisan di media sosial.

\section{SARAN}

Setelah menuntaskan penyuluhan kesantunan berbahasa di media sosial melalui zoom meeting maka dalam kegiatan selanjutnya tim PKM mengusulkan mengadakan kegiatan Sosialiasi Kesantunan Berbahasa di Media Sosial dalam skala besar SeCirebon dengan melibatkan beberapa narasumber lainnya

\section{UCAPAN TERIMA KASIH}

Tim PKM mengucapkan terimakasih kepada Lembaga Pengabdian Masyarakat (LPM) Universitas Swadaya Gunung Jati yang telah memberikan hibah pengabdian masyarakat dan terimakasi juga kepada mitra SMA Al Azhar Cirebon.

\section{DAFTAR PUSTAKA}

Budiwati, T. R. (2017). Kesantunan berbahasa mahasiswa dalam berinteraksi dengan dosen di Universitas Ahmad Dahlan: analisis pragmatik. The 5TH Flurecol Proceeding, UAD, Yogyakarta, 557-571. 
Budiyanto. (2018). Sebarkan Ujaran Kebencian di Facebook, Pelajar di Sukabumi Terancam Dipenjara. Kompas, 3 Maret (diakses, 10 Januari 2020)

Chaer, Abdul. (2010). Kesantunan Berbahasa. Jakarta: Rineka Cipta.

Hymes. D. (1974) Model of Interaction of language ang Social Life. Dalam Gumperz dan Dell Hymes (ed). Direction in Sosiolinguistic. New York: Hold \& Rinehart and Winston.

Leech, Geoffrey. (2011). Prinsip-Prinsip Pragmatik. Jakarta: Universitas Indonesia.

Mahsun. (2012). Metode Penelitian Bahasa, Tahapan Strategi, Metode, dan Tekniknya. Jakarta: Rajawali Press.

Maulidi, A. (2015). Kesantunan Berbahasa pada Media Jejaring Sosial Facebook. BAHASANTODEA, 3(4).

Nugrahani, F. (2017). Penggunaan Bahasa dalam Media Sosial dan Implikasinya terhadap Karakter Bangsa. Stilistika: Kajian Bahasa, Sastra, dan Pembelajarannya, 3(1).

Pranowo. (2012). Berbahasa Secara Santun. Yogyakarta: PustakaPelajar

Rahardi, Kunjana. (2005). Pragmatik; Kesantunan Imperatif Bahasa Indonesia. Jakarta: Erlangga.

Rahayu, S. (2019). Analisis Kesantunan Berbahasa Media Sosial Instagram: Kajian Pragmatik (Doctoral dissertation).

Ristiani, Iis. (2013). Pembudayaan Kesantunan Berbahasa dalam Media Facebook sebagai Upaya Pembinaan Karakter Bangsa. Kongres Bahasa Indonesia X. Jakarta, 28-31 Oktober 2013

Rustono. (1999). Pokok-Pokok Pragmatik. Semarang: IKIP Semarang Press.

Suciartini, N. N. A., \& Sumartini, N. L. P. U. (2018). Verbal Bullying Dalam Media Sosial Ditinjau Dari Perspektif Penyimpangan Prinsip Kesantunan Berbahasa. Ganaya: Jurnal Ilmu Sosial dan Humaniora, 1(1), 104-134.

@ 2021 JagoMipa (https://bimaberilmu.com/jurnal/index.php/jagomipa) 